Wahlgren, Ent. Tidskr. xxxi. 47, f. 3 (1910);

Frey, Acta Fenn. xxxvii. (3) 8 (1913)

imperfecta Loew

Loew, Berl. Ent. Zts. ix. Cent. vi. 82 (1865) Platyenema Aldrich, Cat. Dipt. 342 (1905) ? Platycnema.

\title{
NOTES ON THE BIOLOGY OF CERTAIN WASPS OF THE GENUS ANCISTROCERUS (EUMENID $Æ)^{1}$
}

\section{By Leland H. Taylor.}

During the summer of 1921 , while attempting to get some material for the study of the biology of the Chrysididæ, I was able to make some fragmentary observations on three species of Eumenidæ which I present here.

The biology of various species of Eumenids has received much attention from both European and American observers, whose work cannot be reviewed in this paper. Particular mention should be made of the observations of Fabre (1882, 1884, 1891), Ferton (1895, 1901-1921) and Roubaud (1916) among Europeans, and of the studies of such American workers as the Peckhams (1900, 1905), Hartman (1905), Hungerford and Williams (1912), Isley (1913) and the Raus (1918). With the exception of Ancistrocerus capra de Saussure, the species of Eumenidæ treated in this paper have not been studied, and it is hoped that these notes, if presenting nothing particularly new, will help to confirm previous observations on this highly interesting group.

The species which I have been permitted to observe are apparently those which are usually accustomed to nesting in suitable cracks and crevices of stone and wooden walls. Under ordinary circumstances, therefore, their workings are practically inaccessible, but by the use of artificial nesting places ${ }^{2}$ it has

\footnotetext{
1Contributions from the Entomological Laboratory of the Bussey Institution, Harvard University. No. I98.

2Both solitary wasps and bees have been induced by other investigators to nidificate in tubes of glass. See the papers of Fabre (I884) and Bordage (I9I2).
} 
been possible to keep in close touch with the operations of nest construction and also to observe the development of egg, larva and pupa.

About the middle of June sixty artificial nesting places were put out on the window sills and in other situations near the walls of the Bussey Institution where Eumenids had been noticed searching for places in which to nidificate. These nesting places were crudely and variously constructed, all, however, consisting of glass tubes inserted in holes bored in blocks of wood. A type of the apparatus used is shown in figure 1; others were more simple, but all were so constructed that the tube could be expeditiously removed and replaced. It was found by trial that tubes having an inside diameter of from six to eight millimeters were preferred by the wasps. Individuals repeatedly entered and examined tubes of greater diameter, but in no instance did they make use of them.

That these tubes were acceptable to the wasps is shown by the fact that no less than three started their building within the first three days after the tubes were placed out, one nest having been entirely completed during that time. The device proved to be convenient for the study of the occupants but for two disadvantages. First, the condensation of moisture on the inside of the glass tubes sometimes caused the egg or young larva to adhere to the walls so that it was prevented from reaching its food. The moisture also accelerated bacterial infection which in some cases destroyed both egg or larva and provisions. Second, the activities of the larva after the spinning of the cocoon could not be well observed without breaking the tube.

I wish to thank Doctor Joseph Bequaert of the American Museum of Natural History who has very kindly determined the species of Ancistrocerus mentioned in this paper.

Ancistrocerus tardinotus Bequaert MS.

This species of Ancistrocerus is treated in detail, as I had the opportunity toobserve rather closely the nest-building activities of two females. It will also serve as a type of the work done by other Eumenids which came to my notice. 
Nest No. 2.3 Scarcely 24 hours had passed after the tubes had been placed out, when a wasp was seen (June 13) entering one of them carrying mud or gravel which she got at a driveway 25 feet distant. Between each trip for gravel, which always took several minutes, she took a shorter flight which I could not follow, probably to her water supply. She continued in this way from four until five o'clock P. M., when I was obliged to leave. At six P. M. she entered her nest carrying beneath her body a small green caterpillar, which she quickly deposited, then flew away. Between six and seven o'clock she made about six or seven visits to her nest, each time bearing a similar caterpillar. One of her absences from the nest was of only two or three minutes duration, but usually she did not meet with such prompt success. She spent no more time within the nest than would allow her to deposit her prey. From this time on $\mathrm{I}_{\mathrm{ob}}$ served her only sufficiently to state that she worked quite consistently for the next two days and completed her nest at some time just previous to four P. M. on June 15.

Nest No. 3. On June 16 at four P. M. a wasp of this species, possibly the same one as described above, was seen to enter one of the nesting places not far from nest No. 2. An examination of the tube at this time showed two cells already completed. Out ${ }^{-}$ side the closing partition of the second cell was a third egg and a single caterpillar. The wasp continued to work until seven $P$. M. at which time she had nearly completed the closure of her third cell. During the night she did not occupy the nest as these wasps commonly do, possibly because there was hardly sufficient room. Indeed, it seemed that she would not be able to construct an additional cell in such a limited space. Observations at 5:30 and at 7:30 the next morning showed that the wasp had not resumed her work, but by 8:30 she had already finished the closing partition of the third cell and had laid her fourth egg. During the morning she caught and deposited three caterpillars and at 10:45 she brought the bit of cement that would have closed the last cell had I not captured her for identification before she had been able to apply it.

3The numbers designating the nests described in this paper are the original ones used in my field notes; they are thus not consecutive. 
The two nests built by wasps of this species did not differ greatly from each other or from those constructed by the other wasps noted in this paper. Wasp No. 2 built her nest (Fig. 1) in a tube which had an inside diameter of 7.5 millimeters. It contained four cells whose respective lengths were as follows: cell No. 14, 14mm.; No. 2, 8 mm.; No. 3, $6 \mathrm{~mm}$; and No. 4, $5 \mathrm{~mm}$. In each cell at about two millimeters from the inner wall was suspended from above by means of a fine thread about a millimeter in length a white, glistening egg. The egg, which resembled almost exactly eggs of other members of this genus which I have observed, was about $2.5 \mathrm{~mm}$. long, subcylindrical, concave dorsally (?) and convex ventrally (?) (Fig. 3). In some cells it hung freely; in others, where the provisions were more tightly packed, it was pushed firmly against the upper wall of the cell. Cell No. 1 was provided with ten caterpillars, No. 2 with six, No. 3 with three and No. 4 also with three. The caterpillars were of uniform size, about $12 \mathrm{~mm}$. long and all appeared to be of the same species, probably of the family Tortricidæ. They were imperfectly paralyzed and responded to mechanical stimulus by quick, jerky movements of the abdomen. The head and thorax, however, seemed little capable of movement, the mouth parts and legs scarcely responding to the touch. It would seem then that the sting of the wasp must be introduced in the region of the thorax, thus bringing about partial paralysis of the parts which might tend to injure the egg or young wasp.

The cells of the nest were separated by partitions one millimeter in thickness, constructed of earth of a fine clayey consistency and moistened with water (and perhaps secretions) to form a cement which at first had a brownish color but became gray after drying. The partitions were not laid with precision transversely in the tube, but were often irregular with a slight oblique tilt. The inner surfaces of the partitions appeared more rough than the outer surfaces, due to their having been smoothed out by the wasp's mandibles. In constructing these partitions the wasp first lays down the rim, flattening out her first lump of

4 In designating the cells of a particular nest the numbers I, 2, 3 etc. refer to the order in which the cells were constructed by the wasp. Thus the innermost cell is no. $I$, the next, no. 2 and so on. 
mud between the mandibles and adding further material concentrically within until only a minute opening remains. This she plugs with a small bit of mud and then apparently smooths out the surface of the whole. In the nest of wasp No. 2 a vacant space about $10 \mathrm{~mm}$. long was left between the outermost occupied cell and the entrance. ${ }^{5}$ The closure was flush with the surface of the entrance block; it was a plug of cement twice as thick as the partitions within and not smoothed off outwardly.

The nest of wasp No. 3 was made in a tube which differed slightly from that shown in the figure (Fig. 1) in that the outer end of the tube was flush with the entrance, there being no entrance block. In this nest the outermost cell reached the entrance of the nest, no empty space having been left by the wasp as in the former case. The glass tube had an inner diameter of only 5 $\mathrm{mm}$. The wasp had adapted her construction to this smaller diameter by making the cells longer. The comparative lengths of the cells in this nest and the number of caterpillars provided in each were as follows: cell No.1,-17 mm., 6 caterpillars; No. 2,-17 mm., 7 caterpillars; No. 3,-11 mm., 3 caterpillars; No. 4,-5.5 $\mathrm{mm}$., 3 caterpillars. The caterpillars appeared to be of two species and perhaps represented two families (Pyralidæ and Tortricidæ?).

The following tabulation gives the life histories of the wasps in nests 2 and 3 .

$$
\text { Nest No. } 2 .
$$

$\begin{array}{lcccc}\text { Date of } & \text { Cell No. 1 } & \text { Cell No. 2 } & \text { Cell No. 3 } & \text { Cell No. 4 } \\ & \text { \% } & \sigma^{7} & \text { o } & \sigma^{7} \\ \text { Oviposition } & \text { June 13 } & \text { June 14(?) } & \text { June 14(?) } & \text { June 15(?) } \\ \text { Hatching } & \text { June 16 } & \text { June 17 } & \text { June 17 } & \text { June 18(?) } \\ \text { Cocoon spinning } & * & \text { June 23 } & \text { June 23 } & \text { June 23 } \\ \text { Pupation } & \text { June 30 } & \text { June 29(?) } & \text { June 29(?) } & \text { June 30 } \\ \text { Imagination } & \text { July 13 } & \text { July 9(?) } & \text { July 9 (?) } & \text { July 10(?) } \\ \text { Emergence } & \text { July 15 } & \text { July 11 } & \text { July 11 } & \text { July 11 } \\ \text { Death } & \text { Oct. 15 } & \text { July 19 } & \text { Oct. 15** } & \text { Aug. 17 }\end{array}$

*This wasp curiously spun no cocoon, only a few loose threads. It became inactive June 25 .

**Death of this male may have been hastened by falling into the sirup, supplied as food.

5According to Roubaud (I9I6) such empty cells are evidently for the purpose of confusing parasites. 
Nest No. 3.

Date of

Cell No. 1 Cell No. 2 우 (?)

Cell No. 3 Cell No. 4

Oviposition

June 16(?) June 16 June 16 June 17

Hatching

Cocoon spinning

June 19(?) June 19(?) June 20

Pupation

*

$* *$

June 24 June 25

Imagination

Emergence

Death

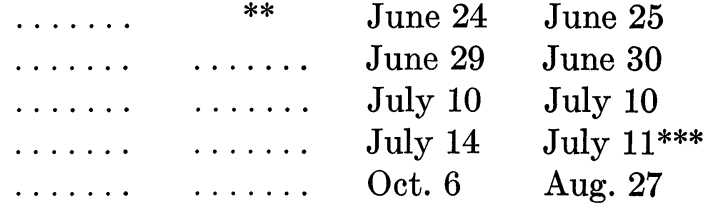

*Did not hatch.

***Died June 22.

for observation.

***Emergence probably premature; cocoon broken open

The above tables give the following as the lengths of the stages in the life of Ancistrocerus tardinotus: egg, 3 days; larva, 10-14 days; pupa, 11-14 days. The larger figure for the larval and pupal stages represents the length of these stages in the single female which reached maturity, from the innermost cell of nest No. 2. The other five individuals which matured from these two nests were all males.

The eggs of this species, like those of other species noted here, show the first sign of hatching by a swelling of the chorion on one or both sides. This seems to be due to the flattening of the larva, the pleura becoming somewhat protuberant. (Fig. 4). The chorion then becomes ruptured at its anterior or lower end, and the minute larva by slow movements works about threequarters of its body out. Thus suspended it remains for half or three-quarters of an hour during which time it appears to derive some nourishment through the integument of the caterpillars which it may be able to reach. Figure 5, sketched from an undetermined larva of Ancistrocerus illustrates the appearance of the larva in this position. Soon freeing itself from the chorion, the larva moves about actively, finally taking a position with its mouth closely applied to the integument of one of its caterpillars often just behind or near the thorax. At first it appears to feed 
without biting the skin of its prey and its feeding is indicated only by the rhythmic movement of its body, but as it increases in size it may be seen to bite rather ferociously at its caterpillar, sinking its mandibles and even its entire head into the now lacerated body. Growth is rapid and usually the food is consumed to the last bit, even the heads being eaten by some of the more voracious individuals. When all the food is gone the larva may be observed moving about its cell, its mandibles constantly working along the walls. Whether it is searching for more food or attempting to begin its cocoon is not entirely evident. At any rate, the result of this activity seems to be that all the detritus in the cell, including the excrement of the caterpillars and whatever of the food supply may occasionally remain uneaten, becomes gathered at one end or along the lower wall of the cell, so that it does not interfere with the spinning of the cocoon. Before actually spinning the cocoon the Ancistrocerus larva makes a rather coarse-meshed network closely applied to the walls of the cell, entirely lining it and excluding all debris. The cocoon is variable in shape, irregularly cylindric-elliptical with one of its ends and its lower surface touching the walls of the cell, usually at the inner and lower end. It is tough, closely woven, translucent and semi-transparent, usually of a pale brownish tint with a slight silky lustre. Figure 2, though perhaps of a different species, illustrates the position of these cocoons in situ. Pupation does not take place immediately, the larva remaining quiescent in the cell for from five to seven days.

As in most nidificating Hymenoptera which construct similar nests, the outermost occupant of the nest is the first to emerge, though it is necessarily the product of the most recent egg laid by the builder. All the males reach the adult stage at about the same time, but until the one nearest the entrance makes its escape, there appears to be no attempt on the part of the others to break out, though they often may have already broken from their cocoons and are free to emerge as soon as the way is clear. Once the first male has made its escape the others follow in rapid succession, the females only remaining after the males have been gone for some little time. 
In the species of Ancistrocerus which have come to my notice, the wasps which have developed from the innermost cells of a nest have been invariably females. These inner cells are always of greater capacity and more bountifully provisioned than the smaller, outer cells, which are destined to give forth males $^{6}$. In a very painstaking study Fabre (1884) found a similar distribution of the sexes in the nests of certain solitary wasps and bees. Later Verhoeff (1892a, 1892b) made like observations and gave the name proterothesie to this phenomenon. Bordage (1912) and Roubaud (1916) have found it also in solitary wasps of the Malagasy and Ethiopian regions. This disposition of the males and females is supposed by authors to permit the males on emerging to fly about and thus come in contact with females from other nests, achieving cross-fertilization. In one of the nests which I had in confinement, however, (nest no. 2) one of the first two emerging males constantly sat at the entrance of the nest from which it had just escaped, apparently waiting for a female. The next wasp to emerge was another male; the new arrival was met with palpations of the antennæ similar to those which precede copulation. In nature, however, this might not have occured.

In confinement copulation was witnessed. The female apparently copulates but once, as the one observed repeatedly rejected males after having been fecundated. The males, on the other hand, are apparently able to fertilize more than one female, since they make repeated attempts after their first mating.

The tables given above show several instances of longevity among individuals of this species, both in males and in the single female, one individual of each sex living longer than three months. Whether the period of life would be as long under normal conditions of subsistence and expenditure of energy is perhaps questionable, but it seems highly probable that a single female lives sufficiently long to construct several nests of the type described in this paper.

6This difference in size is evidently the general rule. Aberrations have been noticed and one of these is shown in figure 2, where cell No. 2 is larger than No. I. This condition seems to be exceptional. 


\section{Ancistrocerus capra de Saussure.}

The habits of this wasp have been recorded briefly by the Peckhams (1900), who describe three successive nests constructed by this species in the mouthpiece of a tin horn. Their observations differ from mine in that they found the duration of the egg stage to be four days instead of two. These authors point out the similarity of the habits of this species to those of the European A. nidulator de Saussure, observed by Fabre (1891). The Raus (1918) have published observations on a nest made by capra in a woody elder twig, in which the innermost cell was of much greater capacity than the seven (one empty) additional cells, but no mention is made of the sex of the wasps reared from the nest. Observations of Rev. T. W. Fyles, reported by Ashmead (1894), show that this species provisions its nest with larvæ of the larch saw-fly (Lygæonematus erichsonii Hartg.) Unfortunately I did not preserve any of the larvæ used by capra, but I am almost certain that in this case they were lepidopterous rather than of saw-flies. It seems probable that species of Ancistrocerus do not limit themselves to a particular kind of caterpillar, but avail themselves of whatever desirable food may be abundant.

Nest No. 6. At 3:30 P. M. on June 20, I observed a large Ancistrocerus apparently just selecting her nesting place. She made repeated entrances, coming out each time and flying off for a short distance, apparently carrying nothing. She was possibly making a long distance locality study. Soon she began to bring in mud, out of which she constructed a basal partition at about $7 \mathrm{~mm}$. from the interior end of the tube. During the construction of this partition I took many liberties with the nest, removing the glass tube during the wasp's absence and sometimes failing to get it replaced before she returned. She seemed little disturbed. Once, as she hovered before the window sill where her nest should have been I slowly placed it in front of her and she entered as though nothing had happened. Perhaps as a result of this interference, she abandoned her first partition and started another about $5 \mathrm{~mm}$. from the first. When this was 
finished the wasp backed out of the tube, turned about and backed in presumably to oviposit, but strangely no egg was laid until half an hour later (5:30 P. M.). At six o'clock she brought in a caterpillar and suspended operations, remaining asleep in the cell all night.

During the building of the partition described above, I removed a small stone which had been resting on the nesting block and placed it a few inches to one side of the nest while the wasp was away. On her return, instead of flying directly to the entrance as she had been doing, she made for a position just beneath the misplaced stone. Discovering her mistake, she soon found her nest by flying about at a few inches from the wall. A little later, while examining the tube during the wasp's absence, I placed the entrance block on the window sill at a short distance from its right position. The wasp returned and entered the hole in the entrance block. Finding nothing behind it, she retreated for some distance, and the nest meanwhile having been replaced, she then entered without hesitation. This would seem to indicate that certain objects, such as the stone, serve as guides to the wasp, but this and further observations show that the wasp is not helpless when such guides are removed, since after once finding her nest in the absence of the stone she apparently made use of other means to locate her nest.

June 21 at 9:15 A. M. wasp No. 6 was carrying in mud. This she deposited and went off again returning with a drop of water shining at her mouth. She was apparently just finishing a partition, for she appeared at the entrance, came out and backed in, remaining within for three minutes to lay an egg. Oviposition finished, she appeared at the entrance and after excitedly waving her antennæ, flew off.

At this time I made a further test of her ability to locate her nest by placing a similar nesting block about five inches away from the original and marking it with the stone which had formerly served as a guide. At 10:00 A. M. the wasp came back, bearing a large green caterpillar; she flew directly to the wrong nest, but did not enter, retreating from it and approaching it 
several times, finally flying to a tree twenty feet distant. The stone was then replaced on the true nest. The wasp returned, still bearing her prey, tried the false nest as before, but almost immediately went to the right nest and entered.

This wasp was captured for identification as she was about to complete her nest at 1 o'clock (June 21).

Nest No. 7. Another Ancistrocerus capra was discovered constructing her nest on the same day at 5 P. M. Two hours later she had made a basal wall of mud, deposited an egg and was resting in the tube.

During the mud-carrying operations of this wasp, I removed the stone which marked her nest and placed it six inches to one side. Returning, she flew directly for a point beneath the removed stone, discovered her error and flew along the wall in a horizontal direction, pausing before another nesting block, similarly located on an adjacent window ledge and similarly marked by a small stone. She hovered in front of this empty nest, still holding the lump of mud she was carrying, then suddenly made a swift flight perpendicularly from the building, turned and made a bee line for her true nest, which she found without delay. The stone was not immediately replaced, but the wasp on subsequent trips entered her nest without hesitation, approaching it, however, in a perpendicular direction, instead of obliquely as she had done before her landmark had been misplaced. When the stone was replaced she continued to enter the nest without confusion.

The second day of this wasp's activities was extremely hot and humid. I had always believed that such a day would be particularly conducive to work with the wasps, and was surprised to find that this individual responded to the heat in much the same manner as her observer, for she remained in her nest the greater part of the day and brought in only three caterpillars, one in the early morning and two in the late afternoon. The following day (June 23) heavy clouds kept off the heat of the sun during the morning so that by ten o'clock four caterpillars had been stored. A half hour later the rim of the closing partition of 
a second cell had been made. The mid-day heat doubtless delayed the closing of the entrance until about 4 P. M., when the wasp was captured before she had quite finished.

The nests built by these two individuals of Ancistrocerus capra were similar to those described for $A$. tardinotus. As mentioned above nest No. 6 had two basal partitions, one $7 \mathrm{~mm}$. from the inner end of the tube and the second about $5 \mathrm{~mm}$. from this. There were four cells, the first, between the two basal partitions, empty; the second, $28 \mathrm{~mm}$. long, was provided with a suspended egg and four caterpillars; the third was $26 \mathrm{~mm}$. in length and had the same amount of provisions with an egg; the fourth cell was $25 \mathrm{~mm}$. long and quite empty, its closing partition, incomplete, was about $12 \mathrm{~mm}$. from the entrance. The entrance was not closed, as the wasp was captured before she had been able to do so. The inside diameter of the tube was $6 \mathrm{~mm}$.

Nest No. 7 contained a tube having an inside diameter of $7.5 \mathrm{~mm}$. Its basal partition was constructed at about $15 \mathrm{~mm}$. from the inner extremity of the tube. The first cell was $25 \mathrm{~mm}$. long and contained its suspended egg and seven caterpillars; the second cell was empty, its length about $40 \mathrm{~mm}$. and at about 8 $\mathrm{mm}$. from its base was a very light rim of cement where the wasp had started and abandoned a partition. The closing partition of this long empty cell was about $12 \mathrm{~mm}$. from the plug which closed the entrance, the latter being incomplete since the wasp was captured during its construction.

I was unsuccessful in rearing the wasps from nest No. 6 . The egg in cell No. 1 adhered to the wall of the tube, because of excessive moisture and did not develop. The second egg became detached from its filament, hatched in two days and lived two days longer, attaining a length of about $7.5 \mathrm{~mm}$., when it succumbed to the unfavorably moist conditions.

The single egg in nest no. 7 hatched (June 23) also in two days, after having become detached from its hanging position. On June 28 it had reached a length of $15 \mathrm{~mm}$. and was vigorously feeding on the remnants of its provisions. In feeding it held itself in a curled up position, its back nearly forming a circle, the 
piece of food held down against its ventral abdominal segments beneath its head. On June 29 it started spinning, but did not finish its cocoon until July 2. Six days later it pupated and on July 24 shed its pupal skin, emerging the next day. In captivity this wasp, a female, lived until August 22, nearly a month after emerging. The lengths of its stages were as follows: egg, 2 days; larva, 15 days; pupa, 16 days.

\section{Ancistrocerus albophaleratus de Saussure.}

Two nests built by wasps of this species came under observation. Ashmead (1894) records it as having been bred from an oak gall in Massachusetts.

Nest No. 14. This nest was started July 4 at about 4 P. M. The nest builder was observed rather constantly until July 10, when she was found dead within the entrance of her uncompleted nest. The preceding day had been rainy and may have brought about her untimely death, but the somewhat erratic construction of her nest may indicate that she was at the end of her resources.

Nest No. 21. This nest of albophaleratus was commenced July 19 and finished five days later. During a cool, wet day the wasp was inadvertently knocked from her nest, while she was apparently sleeping and lost in the grass. Although she returned the next day, her absence may have given an opportunity for a fly to enter her nest and deposit eggs, the larvæ from which later destroyed the entire nest and its contents.

The tube in which nest no. 14 was built had an inside diameter of $7.5 \mathrm{~mm}$. Its inner end being completely closed, the wasp built no basal partition. The first cell was $18 \mathrm{~mm}$. long and contained about 14 caterpillars; the second, $15 \mathrm{~mm}$. in length, contained only six; the third cell, $16 \mathrm{~mm}$. long, was empty; the fourth cell had a very imperfect basal partition, in which spaces had been left and was $10 \mathrm{~mm}$. long. There was an egg suspended in this cell, but no caterpillars had been provided. It was in this cell that the wasp was found dead. A rim of mud about the periphery of its outer end showed that an attempt 
had been made to close the cell. Evidently the wasp had been unable to provision this last cell and was in the act of closing it when she met her death.

The tube utilized by the other wasp of this species (No. 21) had an inside diameter of $6 \mathrm{~mm}$. The nest had three cells, the basal partition of the first having been built about $5 \mathrm{~mm}$. from the plug of cotton which stopped the inner end of the tube. Cell No. 1, 30. mm. long, had 13 caterpillars, cell No. 2, $28 \mathrm{~mm}$. long, had seven and cell No. 3, $13 \mathrm{~mm}$. long, contained eight. All were provided with eggs suspended in the usual manner. The entrance to the nest had no closing plug, the outer wall of the third cell being about $12 \mathrm{~mm}$. from the entrance and the space beyond it was entirely vacant.

Only one wasp from these nests reached maturity, a female. The duration of the stages in her life was as follows; egg, 3 days; larva, 16 days; pupa, 13 days. The larva became inactive about six days after hatching and spun no cocoon. The imago lived thirty-five days.

\section{Miscellaneous Notes.}

Other nests built by undetermined species of Ancistrocerus were observed during the summer, but with most, because of parasites or other unfavorable conditions, the data obtained are too fragmentary to be of further use than to substantiate the findings on the species treated in more detail. In general the observations on these nests are consistent with what has already been recorded.

Nests started later in the summer (four in number, built Aug. 8, 16, 17, and 22) have a somewhat different history. Instead of pupating a few days after spinning, individuals from these nests still remain as larvæ during the winter and will probably not complete their development until the following June.

Not a few nesting places presented evidence of nests having been started by wasps and abandoned in an incipient stage. In some basal partitions were made, never to be utilized. In two 
tubes an initial cell was provided with an egg and several paralyzed caterpillars and then abandoned. In both of these, eggs and caterpillars disappeared within a day, and the presence of ants in both leads me to believe that these depredators may have been guilty of the robbery. Whether the nests were abandoned by their builders before the incursions of these ants or whether the desertion was a result of their intrusion could not be determined. The paralyzed caterpillars and the wasp egg would doubtless be attractive to these insects and it is not unlikely that the presence of a few worker ants in a nest would drive the owner away.

Three nests of Ancistrocerus were infested by dipterous larvæ. In one of these the eggs were very evidently deposited in the nest by the adult fly; the others may have been deposited on the caterpillars before they were brought to the nest. In all three nests the behavior of the fly larvæ was the same-they devoured everything. After consuming the contents in one cell they broke through the mud partition and fed on the contents of the next and so on until the entire nest was destroyed. Attempting to rear the adults for identification, I placed the pupæ of these Diptera in glass tubes fitted with tight cotton plugs, thinking to prevent their escape. But the adults were evidently well provided with means for escaping from wasp's nests, for on emerging they worked their ways through the cotton and were lost.

An undetermined species of Chrysidid, which I shall mention elsewhere, was also associated with wasps of the genus Ancistrocerus observed during the summer of 1921.

\section{Summary and Conclusions.}

Observations on the three species of Eumenidæ treated in this paper (Ancistrocerus tardinotus Bequaert, A. capra de Saussure and $A$. albophaleratus de Saussure) bring out the following facts concerning their biology.

1. These species appear to nest usually in suitable cracks and crevices adapted to their needs. 
2. The nests made by these wasps in glass tubes have the following characteristics:

a. Tubes having diameters of from six to eight millimeters were utilized by the wasps.

b. Nests consist of from one to four cells, these apparently varying in length conversely to the diameter of the tube, the inner cells being usually larger than the outer. The cells are separated by partitions of mud which the wasp makes by mixing fine sand and water.

c. The cells are each provided with an egg, suspended by a filament from above and each contains from three to fourteen caterpillars; these are supplied after the egg has been deposited.

3. The caterpillars are paralyzed by the wasp by stinging probably at some point near the thorax.

4. From rather fragmentary evidence it appears that the larger, inner cells contain eggs which are destined to produce females, while the smaller, outer cells contain those which are to become males.

5. There are probably two generations of these wasps annually, the eggs of the first being laid from mid to late June, the adults from them appearing during the first half of July. The eggs of the second generation are laid during the latter part of July and the first of August, the wasps from them hibernating as larvæ and probably emerging in June.

6. From the longevity of certain of these wasps in captivity it is concluded that the females live long enough to construct several nests of the sort described here.

7. The females are apparently guided to their nests by certain landmarks, but are not helpless when such landmarks are removed or distrubed.

8. Dipterous larvæ, Chrysididæ and perhaps ants have been observed as enemies of the species studied. 


\section{Literature Cited.}

1894 Ashmead, W. H. The habits of the aculeate Hymenoptera, IV, Psyche, 7, pp. 75-79.

1912 Bordage, E. Notes biologiques recueillies a l'Ile de la Réunion. Bull. scient. France et Belg., 7e sér., 46, pp. 29-91.

1882 Fabre, J. H. Nouveaux souvenirs entomologiques (Souvenirs entomologiques, sér. 2), pp. 77-98. Paris, Delagrave.

$1884 \ldots \ldots \ldots \ldots$.......... les Hyménoptères. Ann. Sci. Nat., (6) Zool. 17, Art. 9, pp. 1-53.

$1891 \quad \ldots \ldots \ldots \ldots$. . Souvenirs entomologiques, sér. 4, pp. 162190. Paris, Delagrave.

1895 Ferton, Ch. Observations sur l'instinct de quelques Hyménoptères du genre Odynerus. Act. soc. Linn. Bordeaux, 48, pp. 219-230.

1901-1921 ........... Notes detachées sur l'instinct des Hyménoptéres melliféres et ravisseurs. 1901, sér. 1, * Ann. Soc. ent. France, 70, pp. 83-148; 1902, sér. 2,* ibid., 71, pp. 499-531; 1905, sér. 3,* ibid., 74, pp. 56-104; 1908, sér. 4, ibid., 77, pp. 535-586; 1909, sér. 5, * ibid., 78, pp. 401-422; 1910, sér. 6*, ibid., 79, pp. 145-178; 1911, sér. 7,* ibid., 80, pp. 351-412; 1914, sér. 8*, ibid., 83, pp. $81-119 ; 1921$, sér. 9 , ${ }^{*}$ ibid., 90, pp. 329-375. (The series marked with asterisks have notes on Eumenidæ.)

1905 Hartman, C. Observations on the habits of some solitary wasps of Texas. Bull. Univ. Texas, 65 (Scient. ser., 6), pp. 1-72.

1912 Hungerford, H. B. and Williams, F. X. Biological notes on some Kansas Hymenoptera. Ent. News, 23, pp. 241260.

1913 Isley, D. The biology of some Kansas Eumenidæ. Kans. Univ. Sci. Bull., 7, pp. 335-309.

1900 Peckham, G. W. and E. G. Additional observations on the instincts and habits of the solitary wasps. Bull. Wis. Nat. Hist. Soc., 1 (new ser.), pp. 85-93. 
1905 ..........Wasps, social and solitary. Cambridge, Houghton-Mifflin.

1918 Rau, Phil and Nellie. Wasp studies afield. Princeton, Princeton Univ. Press.

1916 Roubaud, E. Recherches biologiques sur les guêpes solitaires et sociales d'Afrique. La genèse de la vie sociale et l'évolution de l'instinct maternel chez les Vespides. Ann. Sci. Nat. (9) Zool. 1916, pp. 1-160.

1892a Verhoeff, C. Neue und wenige bekannte Gesetze aus der Hymenopteren-Biologie. Zool. Anzeiger, 15, 362-370.

1892b ............Beiträge zur Biologie der Hymenoptera. Zool. Jahrb., Abt. f. Syst., 6, pp. 680-751.

\section{Explanation of Plate IV.}

Fig. 1. Longitudinal section of nesting block, showing glass tube in position and nest no. 2 containing four cells, each with its egg and caterpillars. (2/3 natural size.)

Fig. 2. Nest built by Ancistrocerus sp. showing three cells with larvæ in cocoons. ( $2 / 3$ natural size.)

Fig. 3. Egg of Ancistrocerus sp. with suspending filament. (This and the next two figures enlarged about fifteen times).

Fig. 4. Same egg as in figure 3 , about to hatch.

Fig. 5. Larva (just hatched from egg shown in figure 3) suspended from the shrunken chorion. 


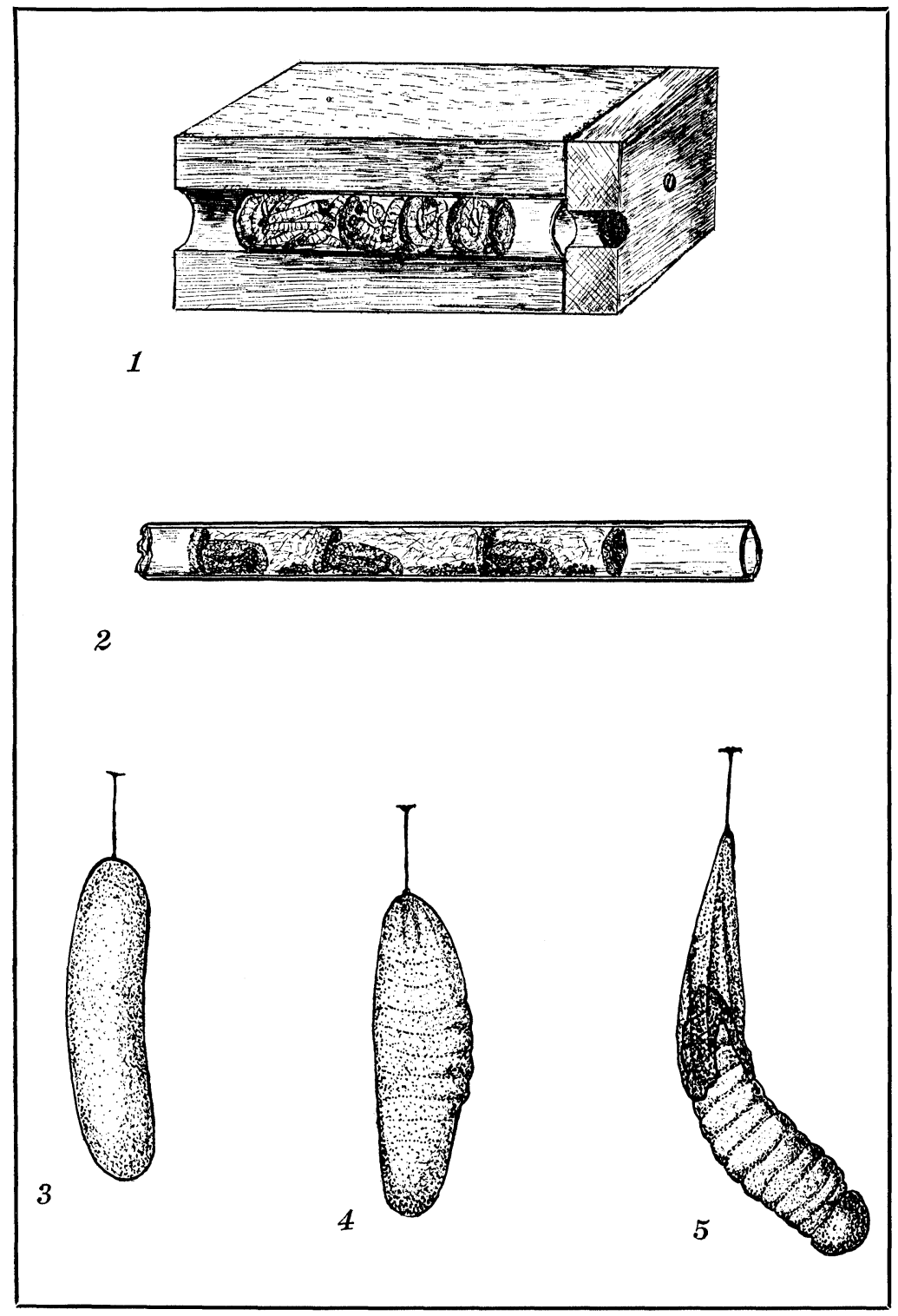

TAYlor-Biology of Ancistrocerus 

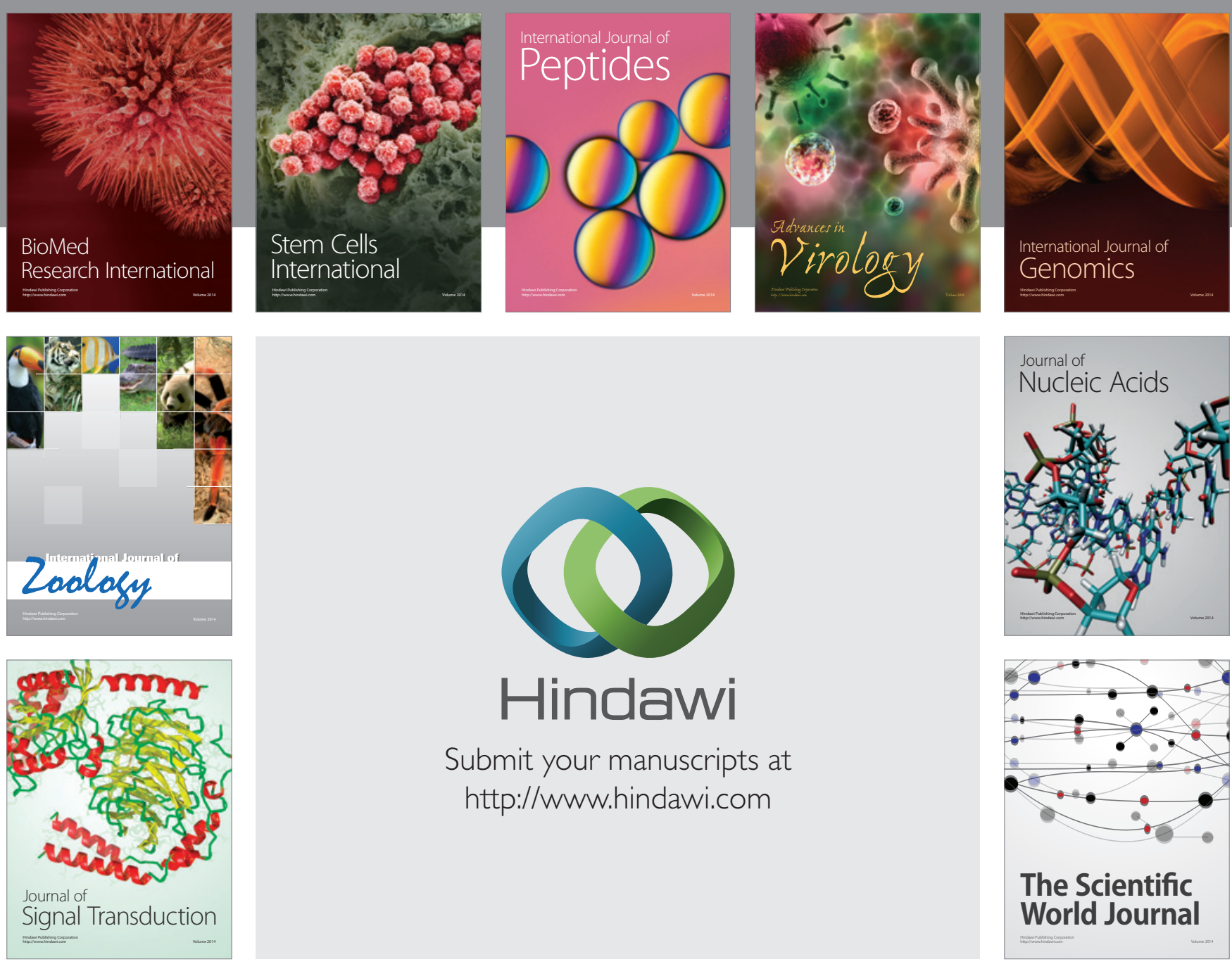

Submit your manuscripts at

http://www.hindawi.com
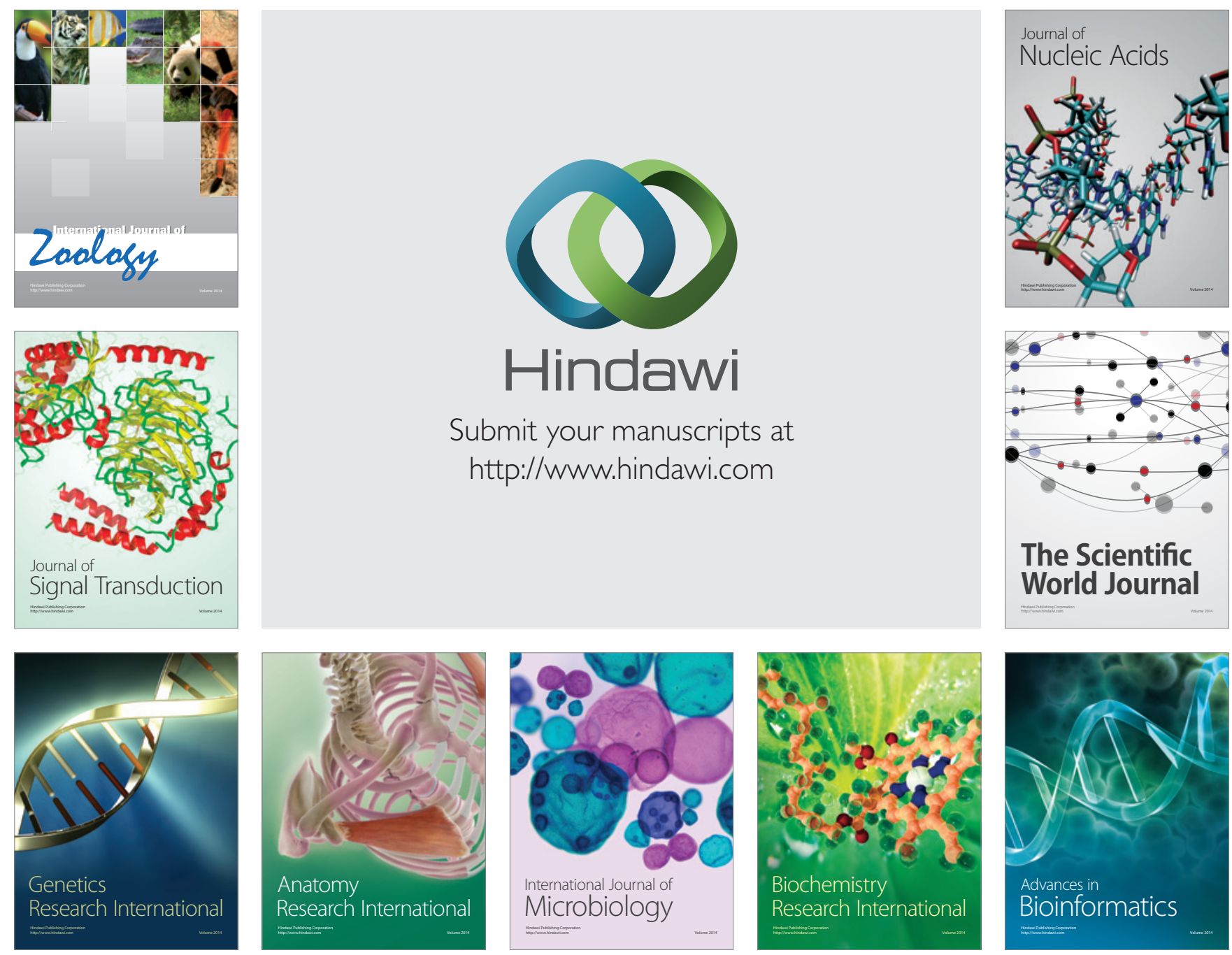

The Scientific World Journal
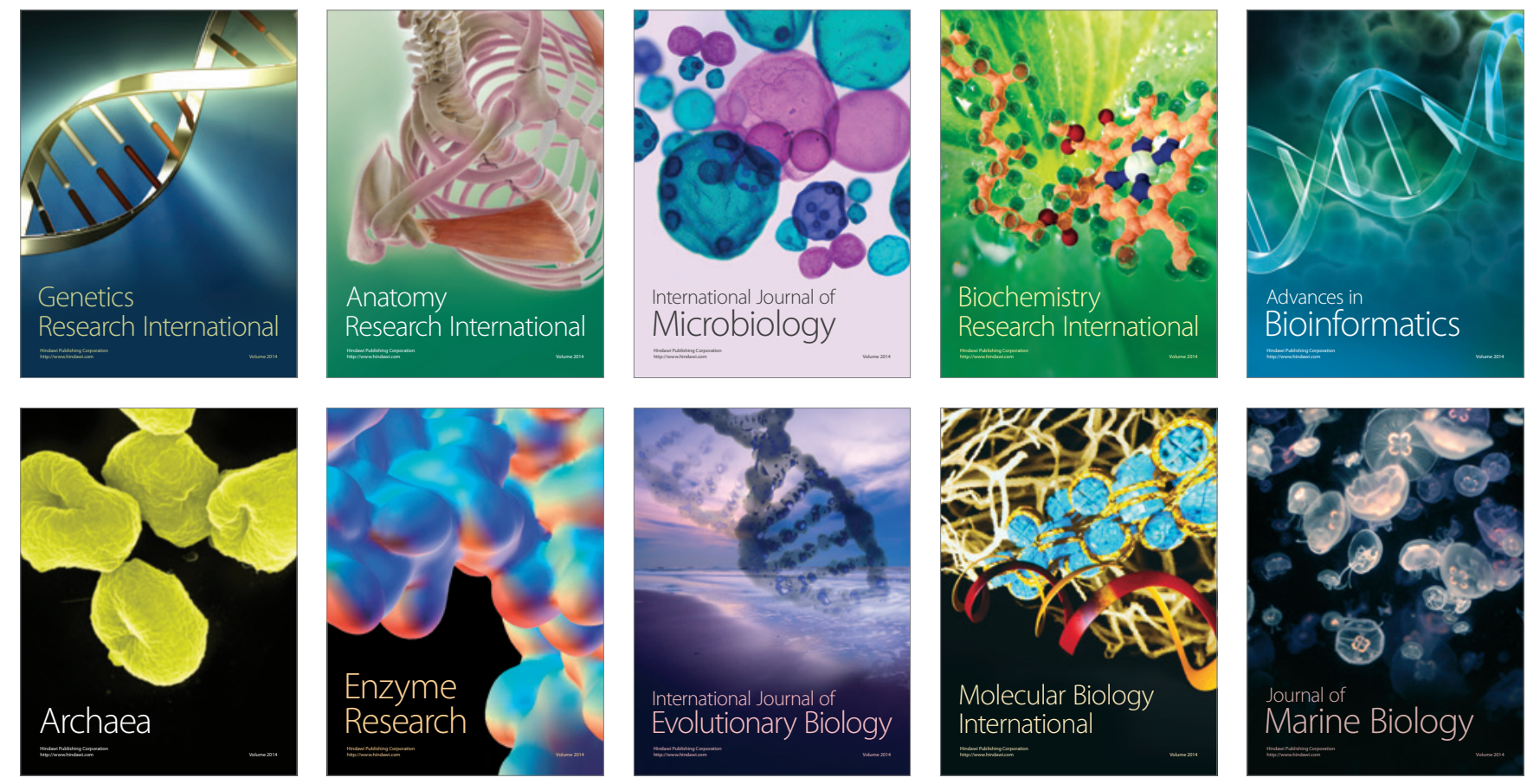